\title{
Pre-treatment serum and plasma levels of matrix metalloproteinase 9 (MMP-9) and tissue inhibitor of matrix metalloproteinases 1 (TIMP-1) in gastric cancer patients
}

\author{
Barbara Mroczko", Magdalena Groblewska', \\ Marta kukaszewicz-Zając ${ }^{1}$, Roman Bandurski², \\ Bogusław Kędra² and Maciej Szmitkowski ${ }^{1, *}$ \\ ${ }^{1}$ Deparment of Biochemical Diagnostics, Medical \\ University, Białystok, Poland \\ ${ }^{2}$ Second Department of General Surgery, Medical \\ University, Białystok, Poland
}

\begin{abstract}
Background: The invasion and metastases of gastric cancer (GC) depends on the activities of matrix metalloproteinases and tissue inhibitors of metalloproteinases. It was suggested that the concentration of plasma matrix metalloproteinase-9 (MMP-9) is better than the concentration of serum MMP-9 for prediction of evolution of GC. The aim of the present study was to compare the clinical usefulness of plasma and serum tissue inhibitor of metalloproteinases-1 (TIMP1) in the diagnosis and prognosis of GC.

Methods: Plasma and serum concentrations of TIMP-1, MMP-9 and carcinoembryonic antigen (CEA) were assayed in 73 patients with GC and 61 healthy controls. The diagnostic criteria and prognostic value for the measurands were defined.

Results: Plasma and serum TIMP-1, MMP-9 and CEA were significantly higher in GC patients compared with healthy controls. The area under the ROC curve (AUC) (0.961), diagnostic sensitivity (89\%) and accuracy $(91 \%)$ of plasma TIMP-1 were higher than those for MMP-9 and CEA. An increased pre-treatment concentration of plasma TIMP-1 was a significant independent prognostic factor for the survival of patients with GC.
\end{abstract}

Conclusions: These findings suggest that the plasma TIMP-1 is a better biomarker than the serum TIMP-1 and might be useful for the diagnosis of GC and prognosis of patient survival.

Clin Chem Lab Med 2009;47:1133-9.

Keywords: gastric cancer; matrix metalloproteinase-9; tissue inhibitor of metalloproteinases-1; tumor markers.

\footnotetext{
*Corresponding author: Professor Maciej Szmitkowski, Department of Biochemical Diagnostics, Medical University, Białystok, Waszyngtona 15a, 15-269 Białystok, Poland Phone: + 4885 7468785, Fax: + 4885 7468585, E-mail: zdb@umwb.edu.pl

Received May 22, 2009; accepted June 16, 2009
}

\section{Introduction}

Gastric cancer (GC) belongs to a group of highmortality malignant tumors of the gastrointestinal tract. The overall long-term survival rate for patients with GC is estimated at $<15 \%$ in Western countries (1). The rapid invasion and metastasis of the tumor are the main causes for the poor prognosis. Tumor invasion is a complex, dynamic, multi-step process, involving the detachment of cancer cells from the point of origin, traversal through the extracellular matrix (ECM) and basement membranes, and invasion into lymphatic vessels. The processes of distant metastases involves intra- and extravasation of cancer cells, reimplantation, formation of stroma and angiogenesis. This process results in formation of a secondary tumor at a distant site (2).

The aggressive growth and metastases of GC may be the result of degradation of the basement membrane which depends on the activities of matrix metalloproteinases (MMPs) and tissue inhibitors of these enzymes tissue inhibitor of metalloproteinases (TIMPs) (3). MMPs belong to the family of structurally, related zinc-dependent endopeptidases and are capable of degrading all the components of ECM (4). The tissue inhibitors of MMPs play an important role in the severity of matrix degradation (5). Enhanced tissue expression of MMP-9 has been observed in various malignant tumors, including lung (6), breast (7), esophagus (8), gastric $(9,10)$, pancreatic (11) and colorectal (12). Some investigations have proven that the expression of MMP-9 (13) and TIMP-1 (14) in GC tissue correlated with tumor invasion and lymph node metastases, and was related to the more aggressive phenotype of this tumor (15).

Increased concentrations of MMP-9 or TIMP-1 have been found in the sera of patients with GC $(9,16-18)$. $\mathrm{Wu}$ et al. suggested that plasma MMP-9 measurement had an advantage over serum MMP-9 determination in prediction of the development and progression of GC (19). However, little is known about plasma concentrations of TIMP-1 in GC patients in comparison with serum concentrations of TIMP-1. It is important to establish whether the differences between serum and plasma samples influence the diagnostic and prognostic values of TIMP-1.

The aim of the present study was to compare the usefulness of plasma and serum TIMP-1 as a biomarker in the diagnosis and prognosis of GC. Additionally, serum and plasma concentrations of MMP-9 and the tumor marker carcinoembryonic antigen (CEA) were determined. Serum and plasma concentrations of the measurands were correlated with clinicopatho- 
logical features of GC. We defined the diagnostic criteria such as the diagnostic sensitivity, accuracy and areas under the receiver operating characteristic (ROC) area under the ROC curve (AUC) for all the proteins tested, and assessed the potential clinical significance of these measurands as biomarkers in the diagnosis and prognosis of GC.

\section{Materials and methods}

A total of 134 subjects were included in the study: 73 previously untreated GC patients ( 23 women and 50 men, aged 28-84 years) diagnosed between April 2003 and May 2008, who underwent surgery at the Second General Surgery Department of the Białystok Medical University Hospital. We also studied 61 healthy volunteers ( 49 women and 12 men, aged 21-69 years). Subjects who had suffered a heart attack or heart failure were not included in the study. Arterial hypertension was observed in 18 cancer patients and diabetes in six patients with GC. The diagnosis of GC was confirmed by microscopic examination of material obtained during biopsy and/or surgery. Assessment of the stage of cancer was based on routine postoperative histopathological analysis and clinical assessment, according to the standard tumor-nodulus-metastases (TNM) classification. Tumors were classified according to the 5th International Union Against Cancer (20): eight cancer patients were in stage lb, nine patients in stage $\mathrm{II}$, seven patients in stage IIla, 15 patients in stage IIllb and 34 patients in stage IV.

For statistical analysis, all patients were divided into three groups based on infiltration of the stomach wall ( $T$ factor: T2 - 13 patients, T3 -33 patients and T4 -27 patients), four groups based on nodal involvement ( $\mathrm{N}$ factor: NO - 17 patients, N1 - 10 patients, N2 - 16 patients, N3 - 30 patients), and two groups based on the presence of distant metastases ( $\mathrm{M}$ factor: $\mathrm{M} 0$ - 45 patients and $\mathrm{M} 1-28$ patients). Patients were observed for 48 months. Thirty-five died of cancer during the observation period. The study was approved by the Human Care Committee of the Medical University in Białystok. Informed consent was obtained from all patients entered into the study.

Blood samples were collected from all patients prior to treatment. None of the patients with GC had received chemo- or radiotherapy before blood collection. Plasma samples from the patients and healthy controls were collected into heparinized sample tubes and centrifuged. To standardize clotting conditions, all sera were separated within $1 \mathrm{~h}$ after blood collection. All samples were stored at $-80^{\circ} \mathrm{C}$ until analysis.

Serum and plasma concentrations of MMP-9 and TIMP-1 were measured using an enzyme-linked immunosorbent assay (ELISA) (R\&D Systems, Abingdon, England) according to the manufacturer's instructions (catalog numbers DMP900 and DTM100, respectively). Samples were diluted 100-fold prior to analysis. Serum and plasma concentrations of CEA were measured using a microparticle enzyme immunoassay (MEIA, catalogue number 7A47-20) (Abbott, Chicago, IL, USA).

The cut-off values for CEA serum and plasma concentrations (the 95th percentile) were established previously in our department by examining blood of healthy volunteers and were $4.0 \mathrm{ng} / \mathrm{mL}$ (21). The cut-off points for serum 1613 $\mathrm{ng} / \mathrm{mL}$ ) and plasma concentrations $(96 \mathrm{ng} / \mathrm{mL})$ of MMP-9 and TIMP-1 (186 ng/mL and $97 \mathrm{ng} / \mathrm{mL}$, respectively) were determined using Microsoft Office Excel software (Microsoft Corporation, Redmond, WA, USA). In the ROC report generated by this program, the cut-off value corresponding to the highest accuracy (minimal false-negative and false-positive results) is indicated by the large dots on the graph.

The results obtained did not follow a normal distribution. Therefore, non-parametric statistical analyses were used. Stages $\mathrm{Ib}$ and II were analyzed as one group (stage $\mathrm{Ib}+\mathrm{II}$ ), whereas stages IIIa and IIIb were analyzed as stage III due to the small number of patients in the subgroups. The MannWhitney U-test was used to compare the two groups in each category (controls vs. GC patients; M0 vs. M1 group; the group of patients who survived vs. patients who died from GC). Differences between other groups (e.g., stage Ib, II, IIla, IIIb, IV; or stage Ib + II, III, IV; or T2, T3, T4; or N0, N1, N2, N3) were compared using ANOVA (Kruskal-Wallis tests). If significant differences were found, the post hoc DwassSteele-Critchlow-Fligner test was performed to determine which groups were different. The prognostic significance of the proteins that were tested was estimated using multivariate analyses with Cox's proportional hazards model. The data are presented as median and range. The differences were considered as statistically significant with $p<0.05$. Additionally, diagnostic criteria such as diagnostic sensitivity, accuracy and AUC were calculated for all proteins. Statistical analyses were performed using the STATISTICA 5.1 PL program (StatSoft Inc., Tulsa, OK, USA). Diagnostic criteria and ROC curves were calculated using Med-Calc statistical software (MedCalc Software, Mariakerke, Belgium) and Microsoft Office Excel program.

\section{Results}

The medians and ranges of MMP-9, TIMP-1 and CEA plasma concentrations are presented in Tables 1 and 2. The concentrations of all proteins tested in patients with GC were significantly higher than those seen in healthy subjects. The plasma concentrations of TIMP1 correlated to depth of tumor invasion (T factor), and were the highest in the T4 subgroup. The plasma con-

Table 1 Median (range) of plasma MMP-9, TIMP-1 and CEA in patients with GC.

\begin{tabular}{lllllll}
\hline Group tested & $\begin{array}{l}\text { Plasma MMP-9, } \\
\mathrm{ng} / \mathrm{mL}\end{array}$ & $\mathrm{p}$-Value & $\begin{array}{l}\text { Plasma TIMP-1, } \\
\mathrm{ng} / \mathrm{mL}\end{array}$ & $\mathrm{p}$-Value & $\begin{array}{l}\text { Plasma CEA, } \\
\mathrm{ng} / \mathrm{mL}\end{array}$ & $\mathrm{p}-$ Value \\
\hline $\begin{array}{l}\text { GC patients } \\
\text { Control group }\end{array}$ & $161(38-1982)$ & $<0.001^{\mathrm{a}}$ & $\begin{array}{r}142(64-426) \\
73(48-119)\end{array}$ & $<0.001^{\mathrm{a}}$ & $\begin{array}{l}1.6(0.0-90.7) \\
0.6(0.0-4.3)\end{array}$ \\
$\begin{array}{l}\text { Tumor stage } \\
\text { Ib + II }\end{array}$ & $137(29-578)$ & & & & & $<0.001^{\mathrm{a}}$ \\
III & $123(59-503)$ & 0.164 & $125(73-333)$ & 0.052 & $1.3(0.3-8.4)$ & 0.534 \\
IV & $175(38-1982)$ & & $130(97-226)$ & & $1.5(0.3-90.7)$ & $1.7(0.0-26.7)$ \\
\hline
\end{tabular}

a Statistically significant when $\mathrm{p}<0.05$. MMP-9, matrix metalloproteinase-9; TIMP-1, tissue inhibitor of metalloproteinases-1; CEA, carcinoembryonic antigen; $\mathrm{GC}$, gastric cancer. 
Table 2 Median (range) of plasma MMP-9, TIMP-1 and CEA in patients with GC in relation to clinicopathological features of tumor.

\begin{tabular}{|c|c|c|c|c|c|c|}
\hline Group tested & $\begin{array}{l}\text { Plasma MMP-9, } \\
\mathrm{ng} / \mathrm{mL}\end{array}$ & $\mathrm{p}$-Value & $\begin{array}{l}\text { Plasma TIMP-1, } \\
\mathrm{ng} / \mathrm{mL}\end{array}$ & $\mathrm{p}$-Value & $\begin{array}{l}\text { Plasma CEA, } \\
\mathrm{ng} / \mathrm{mL}\end{array}$ & $\mathrm{p}$-Value \\
\hline \multicolumn{7}{|c|}{ Gastric wall invasion } \\
\hline $\mathrm{T} 2$ & $175(59-763)$ & \multirow[t]{3}{*}{0.156} & $121(64-333)$ & \multirow[t]{3}{*}{$0.032^{\mathrm{a}}$} & $1.6(0.3-10.5)$ & \multirow[t]{3}{*}{0.786} \\
\hline T3 & $125(44-1982)$ & & $137^{\mathrm{b}}(73-226)$ & & $1.6(0.3-90.7)$ & \\
\hline T4 & $183(38-513)$ & & $165(90-426)$ & & $1.6(0.0-26.7)$ & \\
\hline \multicolumn{7}{|l|}{ Nodal metastases } \\
\hline No & $170(44-763)$ & \multirow{4}{*}{0.496} & $145(73-333)$ & \multirow{4}{*}{$0.022^{\mathrm{a}}$} & $1.5(0.4-8.4)$ & \multirow{4}{*}{0.307} \\
\hline N1 & $105(59-500)$ & & $127(77-262)$ & & $1.3(0.3-38.8)$ & \\
\hline N2 & $155(59-396)$ & & $115^{\mathrm{c}}(64-262)$ & & $1.3(0.0-14.7)$ & \\
\hline N3 & $170(38-1982)$ & & $163(102-426)$ & & $2.1(0.1-90.7)$ & \\
\hline \multicolumn{7}{|c|}{ Distant metastases } \\
\hline Mo & $125(44-763)$ & \multirow[t]{2}{*}{$0.013^{a}$} & $131(73-333)$ & \multirow[t]{2}{*}{$0.006^{\mathrm{a}}$} & $1.4(0.0-90.7)$ & \multirow[t]{2}{*}{0.586} \\
\hline M1 & $209(38-1982)$ & & $163(64-426)$ & & $1.7(0.1-26.7)$ & \\
\hline \multicolumn{7}{|c|}{ Survival of patients } \\
\hline Alive & $136(44-763)$ & \multirow[t]{2}{*}{0.196} & $127(73-333)$ & \multirow[t]{2}{*}{$0.003^{a}$} & $0.4(0.3-38.8)$ & \multirow[t]{2}{*}{0.145} \\
\hline Died from GC & $174(38-1982)$ & & $165(64-426)$ & & $1.8(0.0-90.7)$ & \\
\hline
\end{tabular}

aStatistically significant when $\mathrm{p}<0.05$; ${ }^{\mathrm{b}}$ statistically significant in comparison with T4 (Dwass-Steele-Critchlow-Fligner test); ${ }^{\mathrm{c}}$ statistically significant in comparison with N3 (Dwass-Steele-Critchlow-Fligner test). MMP-9, matrix metalloproteinase-9; TIMP-1, tissue inhibitor of metalloproteinases-1; CEA, carcinoembryonic antigen; GC, gastric cancer.

centrations of MMP-9, TIMP-1 and CEA were found to be higher in the subgroup of N3 patients than those in the N1 and N2 stages, but these differences were significant only for TIMP-1. Plasma MMP-9 and TIMP1 concentrations were significantly higher in the M1 subgroup than in patients without distant metastases. Moreover, plasma concentrations of all the proteins tested were increased in the subgroup of GC patients who died from cancer during the observation period, although the differences were statistically significant for TIMP-1 only.

The concentrations of MMP-9, TIMP-1 and CEA in the sera of patients with GC are presented in Tables 3 and 4. The concentrations of these markers in patients with GC were significantly higher than in healthy controls. Furthermore, serum concentrations of all the proteins were significantly higher than the corresponding plasma concentrations in both GC patients and healthy subjects. Serum MMP-9 and TIMP-1 increased with tumor stage and were highest in patients with stage IV tumors. We found that two stage IV patients with diabetes had serum concentrations of TIMP-1 that were significantly higher than those in patients without diabetes.
The results obtained for the serum concentrations of proteins were similar to plasma concentrations with respect to depth of tumor invasion (T factor) and distant metastases (M factor). Serum TIMP-1 was significantly higher in the T4 subgroup than in T3 patients. In addition, the concentrations of MMP-9 and TIMP-1 in the sera of GC patients were significantly higher in the M1 subgroup than in patients without distant metastases. Serum concentrations of all proteins were higher in GC patients who died from cancer compared with those who survived, although the differences were not statistically significant.

The correlation between pre-treatment concentrations of MMP-9, TIMP-1, CEA and prognosis of patients with GC was evaluated using the method of Kaplan and Meier (22). Univariate analysis revealed that the stage of the disease TNM, depth of tumor invasion (T), lymph node metastases (N), distant metastases (M) and plasma or serum concentrations of TIMP-1 were statistically significant prognostic factors (Table 5). Multivariate regression analysis with Cox's proportional hazards model included only factors which were significant in the univariate analysis. It was found that tumor stage $(p=0.003, O R=6.719)$

Table 3 Median (range) of serum MMP-9, TIMP-1 and CEA in patients with GC.

\begin{tabular}{|c|c|c|c|c|c|c|}
\hline Group tested & $\begin{array}{l}\text { Serum MMP-9, } \\
\mathrm{ng} / \mathrm{mL}\end{array}$ & $p$-Value & $\begin{array}{l}\text { Serum TIMP-1, } \\
\mathrm{ng} / \mathrm{mL}\end{array}$ & p-Value & $\begin{array}{l}\text { Serum CEA, } \\
\mathrm{ng} / \mathrm{mL}\end{array}$ & $\mathrm{p}$-Value \\
\hline GC patients & $669(125-2117)$ & \multirow[t]{2}{*}{$<0.001^{\mathrm{a}}$} & $223(121-590)$ & \multirow[t]{2}{*}{$<0.001^{\mathrm{a}}$} & $1.6(0.1-120.3)$ & \multirow[t]{3}{*}{$<0.001^{\mathrm{a}}$} \\
\hline Control group & $397(76-2696)$ & & $163(106-276)$ & & $0.7(0.1-3.9)$ & \\
\hline \multicolumn{6}{|l|}{ Tumor stage } & \\
\hline $\mathrm{Ib}+\mathrm{II}$ & $413^{b}(125-1374)$ & \multirow[t]{3}{*}{$0.019^{\mathrm{a}}$} & $200(121-423)$ & \multirow[t]{3}{*}{$0.047^{a}$} & $1.8(0.4-6.9)$ & \multirow[t]{3}{*}{0.516} \\
\hline III & $644(286-2117)$ & & $203(122-323)$ & & $1.3(0.3-120.3)$ & \\
\hline IV & $756(206-2070)$ & & $238(145-590)$ & & $1.6(0.1-25.5)$ & \\
\hline
\end{tabular}

${ }^{a}$ Statistically significant when $\mathrm{p}<0.05$; ${ }^{\mathrm{b}}$ statistically significant in comparison with stage IV (Dwass-Steele-Critchlow-Fligner test). MMP-9, matrix metalloproteinase-9; TIMP-1, tissue inhibitor of metalloproteinases-1; CEA, carcinoembryonic antigen; GC, gastric cancer. 
Table 4 Median (range) of serum concentrations of MMP-9, TIMP-1 and CEA in patients with GC in relation to clinicopathological features of tumor.

\begin{tabular}{|c|c|c|c|c|c|c|}
\hline Group tested & $\begin{array}{l}\text { Serum MMP-9, } \\
\mathrm{ng} / \mathrm{mL}\end{array}$ & $p$-Value & $\begin{array}{l}\text { Serum TIMP-1, } \\
\mathrm{ng} / \mathrm{mL}\end{array}$ & $\mathrm{p}$-Value & $\begin{array}{l}\text { Serum CEA, } \\
\mathrm{ng} / \mathrm{mL}\end{array}$ & p-Value \\
\hline \multicolumn{7}{|c|}{ Gastric wall invasion } \\
\hline $\mathrm{T} 2$ & $502(125-1374)$ & 0.242 & $200(144-423)$ & $0.047^{a}$ & $1.8(0.4-11.9)$ & 0.718 \\
\hline T3 & $638(135-2117)$ & & $210^{\mathrm{b}}(121-323)$ & & $1.5(0.1-120.3)$ & \\
\hline T4 & 737 (206-2070) & & $243(145-590)$ & & $1.6(0.5-25.5)$ & \\
\hline \multicolumn{7}{|c|}{ Nodal metastases } \\
\hline No & $444(125-1374)$ & 0.131 & $213(121-423)$ & 0.060 & $1.4(0.1-6.9)$ & 0.175 \\
\hline N1 & $606(251-2117)$ & & $202(144-338)$ & & $1.2(0.6-40.6)$ & \\
\hline N2 & $654(264-2070)$ & & $197(122-281)$ & & $1.4(0.3-18.5)$ & \\
\hline N3 & $743(206-2044)$ & & $238(145-590)$ & & $2.2(0.6-120.3)$ & \\
\hline \multicolumn{7}{|c|}{ Distant metastases } \\
\hline Mo & $622(125-2117)$ & $0.004^{\mathrm{a}}$ & $203(121-423)$ & $0.002^{\mathrm{a}}$ & $1.7(0.3-120.3)$ & 0.725 \\
\hline M1 & $943(206-2070)$ & & $249(145-590)$ & & $1.5(0.1-25.5)$ & \\
\hline \multicolumn{7}{|c|}{ Survival of patients } \\
\hline Alive & $572(135-2117)$ & 0.154 & $207(121-423)$ & 0.107 & $1.3(0.1-40.6)$ & 0.085 \\
\hline Died of GC & 737 (125-2070) & & $234(144-590)$ & & $2.0(0.5-120.3)$ & \\
\hline
\end{tabular}

aStatistically significant when $\mathrm{p}<0.05$; ${ }^{\mathrm{b}}$ statistically significant in comparison with T4 (Dwass-Steele-Critchlow-Fligner test). MMP-9, matrix metalloproteinase-9; TIMP-1, tissue inhibitor of metalloproteinases-1; CEA, carcinoembryonic antigen; GC, gastric cancer.

Table 5 Results of Cox's univariate analysis in patients with gastric cancer.

\begin{tabular}{lcc}
\hline & Odds ratio & $\mathrm{p}$-Value \\
\hline Tumor stage & & $<0.001^{\mathrm{a}}$ \\
Tumor size (T factor) & & $0.003^{\mathrm{a}}$ \\
T3 vs. T2 & 1.099 & 0.876 \\
T4 vs. T2 & 3.823 & $0.018^{\mathrm{a}}$ \\
N factor & & $0.001^{\mathrm{a}}$ \\
N1 vs. N0 & 0.796 & 0.843 \\
N2 vs. N0 & 2.632 & 0.187 \\
N3 vs. N0 & 7.608 & $0.001^{\mathrm{a}}$ \\
M factor & 6.350 & $<0.001^{\mathrm{a}}$ \\
Plasma MMP-9 & 1.000 & 0.549 \\
Plasma TIMP-1 & 1.010 & $<0.001^{\mathrm{a}}$ \\
Plasma CEA & 1.002 & 0.831 \\
Serum MMP-9 & 1.001 & 0.107 \\
Serum TIMP-1 & 1.004 & $0.034^{\mathrm{a}}$ \\
Serum CEA & 1.003 & 0.648 \\
\hline
\end{tabular}

astatistically significant when $p<0.05$. MMP-9, matrix metalloproteinase-9; TIMP-1, tissue inhibitor of metalloproteinases-1; CEA, carcinoembryonic antigen.

and plasma TIMP-1 concentrations $(p=0.002, O R=$ 1.009) were independent prognostic factors for survival of patients with GC.

The percentage of increased concentrations of proteins in patients with GC (diagnostic sensitivity) is shown in Figure 1. The diagnostic sensitivity of serum and plasma TIMP-1 is higher than that of MMP-9 and CEA. The frequency of increased concentrations is the highest for the combination of MMP-9 with TIMP-1 plasma concentrations (97\%). Moreover, the plasma TIMP-1 ROC AUC (0.961) is higher than the AUC for plasma and serum concentrations of the other markers (Figures 2 and 3). The accuracy of plasma and serum concentrations of proteins was also calculated. It was found that the accuracy of plasma and serum TIMP-1 (91\% and 79\%, respectively) was higher than that of plasma and serum MMP-9 $(66 \%$ and $69 \%$,

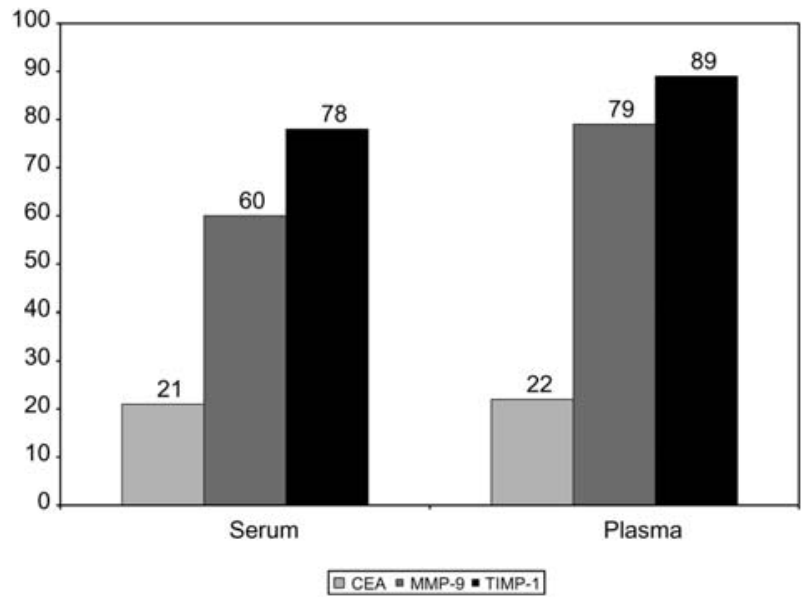

Figure 1 Percentage of patients with gastric cancer with increased concentrations (diagnostic sensitivity) of MMP-9, TIMP-1 and CEA.

respectively) and CEA (both plasma and serum $57 \%)$.

\section{Discussion}

MMPs are involved in the mechanisms of tumor invasion and formation of distant metastases (23). These proteolytic enzymes can be produced by stromal or tumoral cells. TIMPs are induced in stromal cells to control proteinase reactions (24). It was shown that increased expression of MMPs and TIMPs plays a key role in invasion and/or metastasis of GC (25). Koyama suggested that the enhanced cell surface expression of MMPs and TIMPs on inflammatory cells in GC tissue might be a result of the host's response that is induced by tumor (25). Moreover, de Mingo et al. indicated that the tumor tissue concentrations of MMP-9 


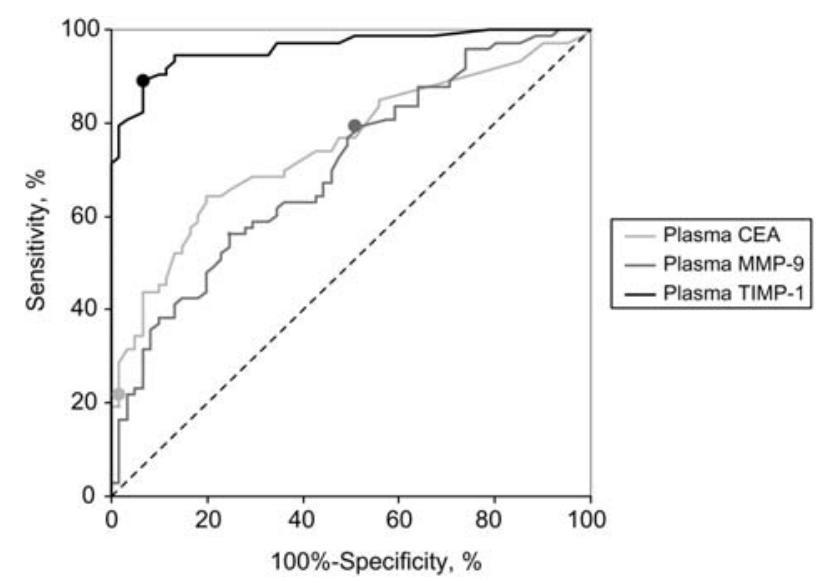

Figure 2 The areas under the ROC curves for plasma TIMP-1 (AUC $=0.9611$; cut-off $97 \mathrm{ng} / \mathrm{mL}$ ), CEA (AUC $=0.7497$; cut-off $4.0 \mathrm{ng} / \mathrm{mL}$ ) and MMP-9 (AUC=0.7045; cut-off $96 \mathrm{ng} / \mathrm{mL}$ ) in patients with gastric cancer.

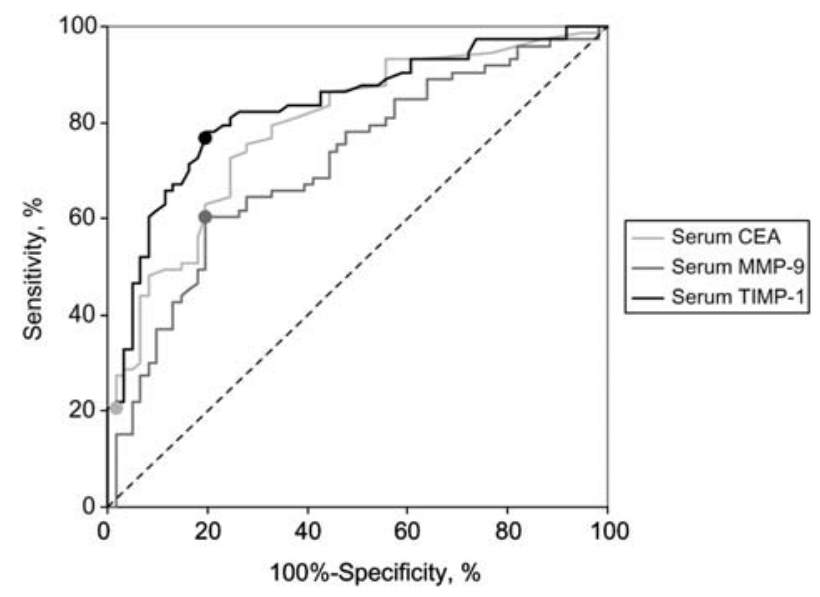

Figure 3 The areas under the ROC curves for serum TIMP-1 ( $A \cup C=0.8320$; cut-off $186 \mathrm{ng} / \mathrm{mL}$ ), CEA (AUC $=0.7915$; cut-off $4.0 \mathrm{ng} / \mathrm{mL}$ ) and MMP-9 (AUC $=0.7141$; cut-off $613 \mathrm{ng} / \mathrm{mL}$ ) in patients with gastric cancer.

and TIMP-1 in GC were significantly higher than in non-tumor tissue and related to a more aggressive phenotype of this tumor (15). However, they did not assess serum or plasma concentrations of these proteins. Wu et al. found increased concentrations of plasma MMP-9 in patients with GC (19). It was indicated that the concentration of plasma MMP-9 is more accurate than serum MMP-9 in the prediction of evolution of GC (19).

The objective of the present study was to investigate plasma and serum TIMP- 1 as well as MMP-9 and CEA in patients with GC. The concentrations of MMP-9, TIMP-1 and CEA were correlated with clinicopathological features of GC. In the current study, serum and plasma concentrations of all proteins tested in GC patients were significantly higher than concentrations seen in healthy controls. These observation are in agreement with the study by Wu et al. (19), where plasma MMP-9 concentrations were higher in patients with GC compared with control patients.
They demonstrated that increased plasma MMP-9 correlated significantly with lymph node metastasis as well as lymphatic and venous invasion (19). In our study, serum concentrations of MMP-9 increased significantly with tumor stage and were higher in advanced stages (IV) when compared with early stages. Additionally, in the current study, serum and plasma concentrations of MMP-9 were significantly higher in patients with distant metastases (M1) compared with the M0 group. Also, we found that the concentrations of plasma and serum TIMP-1 increased significantly with gastric wall invasion and the presence of distant metastases. Yoshikawa et al. (26) demonstrated that plasma TIMP-1 correlated significantly with tumor stage, lymph node metastases and the presence of peritoneal and liver metastases, but they did not measure serum concentrations of this protein. Wang et al. (17) proved that serum TIMP-1 positively associated with tumor size, depth of wall invasion, lymph node metastases, liver metastases, and peritoneal seeding, as well as with lymphatic invasion, perineural invasion, and pathological stage. However, they did not compare these findings with plasma TIMP-1 concentrations. In our study, serum concentrations of TIMP-1 and MMP-9 were higher than those in plasma. It is possible that blood sampling and processing may influence the concentrations of TIMP-1 and MMP-9. These findings may also be the result of platelet activation or neutrophil mobilization during clotting.

Other studies have demonstrated that concentrations of MMP-9 and TIMP-1 increased in patients who had experienced a heart attack or heart failure or suffered from arterial hypertension and diabetes $(27,28)$. In our study, patients who had suffered a heart attack or heart failure were not included. However, arterial hypertension was observed in 18 cancer patients and diabetes was found in six subjects with GC. Two patients with diabetes had serum concentrations of TIMP-1 that were significantly higher than those in patients without diabetes. Therefore, it is important to take into consideration the influence of diabetes and hypertension on the concentrations of metalloproteinases and their inhibitors in patients with GC.

We investigated whether concentrations of MMP-9 and TIMP-1 could be useful as prognostic factors in patients with GC. Univariate analysis showed that increased plasma and serum TIMP-1, as well as tumor stage, depth of tumor invasion (T factor), lymph node (N) and distant metastases (M) were significant prognostic factors. Multivariate regression analysis showed that plasma TIMP-1 may be an independent prognostic factor for survival of patients with GC. As far as we can ascertain, the present paper is one of the first studies to evaluate prognostic significance of serum and plasma concentrations of TIMP-1 in GC patients in comparison with MMP-9 and CEA. Our results add to those of Yoshikawa et al. (29), who showed that plasma TIMP-1 is a strong independent prognostic factor for the long-term survival of patients with GC. 
We defined the diagnostic criteria including the diagnostic sensitivity and the ROC AUC for the markers we evaluated to assess their potential clinical significance for the diagnosis of GC. We found that the percentage of increased plasma concentrations (diagnostic sensitivity) of TIMP-1 (89\%) was higher than that of MMP-9 (79\%) and CEA (22\%) and increased with the combined use of TIMP-1 with plasma MMP-9 (97\%). In addition, the ROC AUC for plasma TIMP-1 $(0.9611)$ and the diagnostic accuracy $(91 \%)$ were higher than that for the other proteins tested in patients with GC. These findings suggest that plasma TIMP-1 is the best diagnostic marker for GC among the proteins we evaluated.

In conclusion, this study compared plasma and serum concentrations of TIMP-1 with MMP-9 and CEA in patients with GC. The results obtained demonstrate the potential clinical value of plasma TIMP-1 as a prognostic factor for the survival of patients with GC and suggest a greater clinical usefulness for plasma TIMP-1 compared with serum TIMP-1 or serum or plasma MMP-9 in the diagnosis of GC.

\section{References}

1. Alexander HR, Kelsen DP, Tepper JE. Cancer of the stomach. In: DeVita VT, Hellman S, Rosenberg SA, editors. Cancer. Principles and practice of oncology, 5th ed. Philadelphia: Lippincott-Raven Publisher, 1997:1021-2.

2. Ray JM, Stetler-Stevenson WG. The role of matrix metalloproteases and their inhibitors in tumour invasion, metastasis and angiogenesis. Eur Respir J 1994;7:206272 .

3. Crawford HC, Matrisian LM. Tumor and stromal expression of matrix metalloproteinases and their role in tumor progression. Invasion Metastasis 1995;14:234-45.

4. Wagenaar-Miller RA, Gorden L, Matrisian LM. Matrix metalloproteinases in colorectal cancer: is it worth talking about? Cancer Metastasis Rev 2004;23:119-35.

5. Gomez DE, Alonso DF, Yoshiji H, Thorgeirsson UP. Tissue inhibitors of metalloproteinases: structure, regulation and biological functions. Eur J Cell Biol 1997;74: 111-22.

6. Leinonen T, Pirinen R, Böhm J, Johansson R, Ropponen $\mathrm{K}$, Kosma VM. Expression of matrix metalloproteinases 7 and 9 in non-small cell lung cancer. Relation to clinicopathological factors, beta-catenin and prognosis. Lung Cancer 2006;51:313-21.

7. Wu ZS, Wu Q, Yang JH. Prognostic significance of MMP9 and TIMP-1 serum and tissue expression in breast cancer. Int J Cancer 2008;122:2050-6.

8. Ohashi K, Nemoto T, Nakamura K, Nemori R. Increased expression of matrix metalloproteinase 7 and 9 and membrane type 1-matrix metalloproteinase in esophageal squamous cell carcinomas. Cancer 2000;10:2201-9.

9. Tan SY, Wang JY, Shen L, Luo HS, Shen ZX. Relationship between preoperative staging by endoscopic ultrasonography and MMP-9 expression in gastric carcinoma. World J Gastroenterol 2007;13:2108-12.

10. Vidal O, Soriano-Izquierdo A, Pera M, Elizalde JI, Palacín A, Castells A, et al. Positive VEGF immunostaining independently predicts poor prognosis in curatively resected gastric cancer patients: results of a study assessing a panel of angiogenic markers. J Gastrointest Surg 2008; 12:1005-14.
11. Jones LE, Humphreys MJ, Campbell F, Neoptolemos JP, Boyd MT. Comprehensive analysis of matrix metalloproteinase and tissue inhibitor expression in pancreatic cancer: increased expression of matrix metalloproteinase-7 predicts poor survival. Clin Cancer Res 2004;10: 2832-45.

12. Herszényi L, Sipos F, Galamb O, Solymosi N, Hritz I, Miheller $\mathrm{P}$, et al. Matrix metalloproteinase-9 expression in the normal mucosa-adenoma-dysplasia-adenocarcinoma sequence of the colon. Pathol Oncol Res 2008;14: 31-7.

13. Sun $W H$, Sun $Y L$, Fang RN, Shao $Y, X u H C$, Xue QP, et al. Expression of cyclooxygenase-2 and matrix metalloproteinase- 9 in gastric carcinoma and its correlation with angiogenesis. Jpn J Clin Oncol 2005;35:707-13.

14. Seo YS, Park JJ, Kim JH, Kim JY, Yeon JE, Kim JS, et al. Usefulness of MMP-9/TIMP-1 in predicting tumor recurrence in patients undergoing curative surgical resection for gastric carcinoma. Dig Dis Sci 2007;52:7539.

15. de Mingo $M$, Morán $A$, Sánchez-Pernaute $A$, Iniesta $P$, Díez-Valladares L, Pérez-Aguirre $E$, et al. Expression of MMP-9 and TIMP-1 as prognostic markers in gastric carcinoma. Hepatogastroenterology 2007;54:315-9.

16. Shen KH, Chi CW, Lo SS, Kao HL, Lui WY, Wu CW. Serum matrix metalloproteinase-9 level associated with stromal reaction in patients with gastric cancer. Anticancer Res 2000;20:1307-10.

17. Wang CS, Wu TL, Tsao KC, Sun CF. Serum TIMP-1 in gastric cancer patients: a potential prognostic biomarker. Ann Clin Lab Sci 2006;36:23-30.

18. Matsui H, Kubochi K, Shimada A, Hasumi A. Desmoplastic response in scirrhous gastric carcinoma: imbalance between collagen synthesis and degradation. Anticancer Res 2000;20:4733-8.

19. Wu CY, Wu MS, Chiang EP, Chen YJ, Chen CJ, Chi NH, et al. Plasma matrix metalloproteinase-9 level is better than serum matrix metalloproteinase-9 level to predict gastric cancer evolution. Clin Cancer Res 2007;13:205460.

20. Jass JR, Sobin LH. WHO International Histological Classification of Tumors. Histological typing of Intestinal Tumors. New York: Springer-Verlag, 1989.

21. Groblewska M, Mroczko B, Wereszczyńska-Siemiatkowska U, Myśliwiec P, Kedra B, Szmitkowski M. Serum levels of granulocyte colony-stimulating factor (G-CSF) and macrophage colony-stimulating factor (M-CSF) in pancreatic cancer patients. Clin Chem Lab Med 2007;45: 30-4.

22. Lawless JF. Statistical models and methods for lifetime data. New York: John Wiley \& Sons Inc., 1982.

23. Vihinen $P$, Kähäri $V-M$. Matrix metalloproteinases in cancer: prognostic markers and therapeutic targets. Int J Cancer 2002;99:157-66.

24. Sato H, Kida Y, Mai M, Endo Y, Sasaki T, Tanaka J, et al. Expression of genes encoding type IV collagen-degrading metalloproteinases and tissue inhibitors of metalloproteinases in various human tumor cells. Oncogene 1992;7:77-83.

25. Koyama S. Enhanced cell surface expression of matrix metalloproteinases and their inhibitors, and tumorinduced host response in progression of human gastric carcinoma. Dig Dis Sci 2004;49:1621-30.

26. Yoshikawa T, Tsuburaya A, Kobayashi O, Sairenji M, Motohashi H, Yanoma S, et al. Prognostic value of tissue inhibitor of matrix metalloproteinase- 1 in plasma of patients with gastric cancer. Cancer Letters 2000;151: 81-6.

27. Tayebjee $\mathrm{MH}$, Nadar S, Blann AD, Gareth Beevers D, 
MacFayden RJ, Lip GY. Matrix metalloproteinase-9 and tissue inhibitor of metalloproteinase-1 in hypertension and their relationship to cardiovascular risk and treatment: a substudy of the Anglo-Scandinavian Cardiac Outcomes Trial (ASCOT). Am J Hypertens 2004;17:7649.

28. Derosa G, D'Angelo A, Tinelli C, Devangelio E, Consoli
A, Miccoli R, et al. Evaluation of metalloproteinase 2 and 9 levels and their inhibitors in diabetic and healthy subjects. Diabetes Metab 2007;33:129-34.

29. Yoshikawa T, Cho H, Tsuburaya A, Kobayashi O. Impact of plasma tissue inhibitor of metalloproteinase-1 on long-term survival in patients with gastric cancer. Gastric Cancer 2009;12:31-6. 